\title{
古レールを使用した忍川橋梁群に関する考察*
}

\section{A Study on Bridges with UsedRail over the Oshikawa River}

\author{
渡辺 明子 Akiko Watanabe** \\ 伊藤 學 Manabu Ito*** \\ 篟田 陽 Yoichi Kubota****
}

\begin{abstract}
概要
埼玉県行田市内を流れる忍川に古レールを使用した上路アーチ橋を 15 橋ほど発見し、 いずれも昭和 8 年と 30 年に設計・施工されたものであることが判明した。3 径間（橋

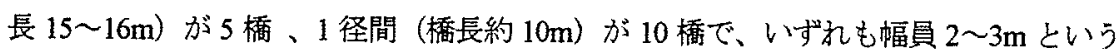
小規模なものだが、このような鉄道界とは全く関係のない町中の道路橋に、主要部材 として古レールが使用されている例は他にはあまりないであろうと考え、今回の研究 に至った。本研究はこれら忍川橋梁群の調查を行い、その特徴、時代背景との関倸に ついて考察したものである。
\end{abstract}

\section{1.はじめに}

前回の報告 ")で、明治元 (1868) 年〜昭和 20 (1945) 年に埼玉県内に架設された歴史的橋梁を調查し、そ の結果を考察しデータベースとして蓄橨した。その なかで特徽的な橋梁群として行田市忍川沿いに架け られている上路鋼ア一千橋を紹介した。当初は 4 橋 しか確認しておらず、詳しく調査を行わなかったた めアーチ部分の鋼材が古レールを使用したものであ ることがわからなかった。市役所の台帳により昭和 8 年に架設されたことが分かっただけで、なぜエの字 型の鋼材を使用したか、どのような考えからこの形 を思いついたのかなど、疑問点が多く、小規模でもこ のようなユニークな橋に注目することも重要である と考え再調查を行った。鋼材部分をよくみると銅材 に刻印（腹部の浮き出しマーク）があり、古レールを
再利用していることが推測された、と同時に、鉄道界 以外で主要部材として古レールを使用しているのは 他にないであろうと更に調查を進めていくことにし た。写真 1 洸当初確認した 3 径間の橋である。再調

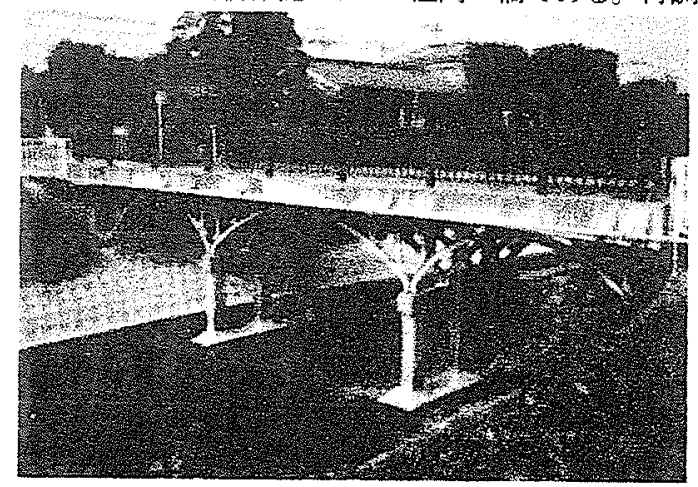

写真 1 忍川のアーチ灀（3 径間）

（撮影：渡辺、1995）

\footnotetext{
*kyeword : 古レール、忍川橋梁群

**学生会員 埼玉大学大学院 理工学研究科

***正会員 東京大学名兴教授

****正会員 埼玉大学教授 工学部建設工学科（广338 埼玉県浦和市下大久保 255）
} 
查で確認できた 1 径間の橋を写真 2 に示す。各橋梁 の所在は図 1 の通りである。

\section{2. 古レール再利用の背景}

\section{（1）時代背景}

鉄道の輸送量が增加してくると機関車の重量も大 きくなり、さらに技術の问上から速度も上昇してく る、レールにかかる全重量が大きくなって、軌道の強 化が望まれレール重量の増加が図られる。このため 当初の使用限度に達して取り替えられた古レールが 大量に発生する。そのような古レールは負荷の低い

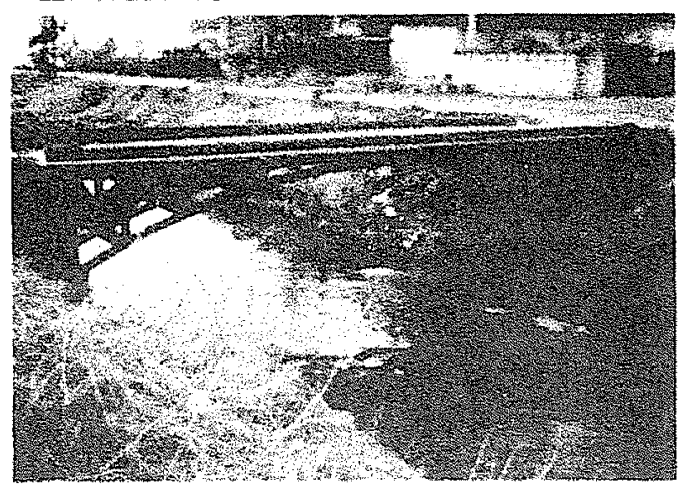

写真 2 忍川のアーチ橋 (1 经間)

(撮影：渡辺、1996)

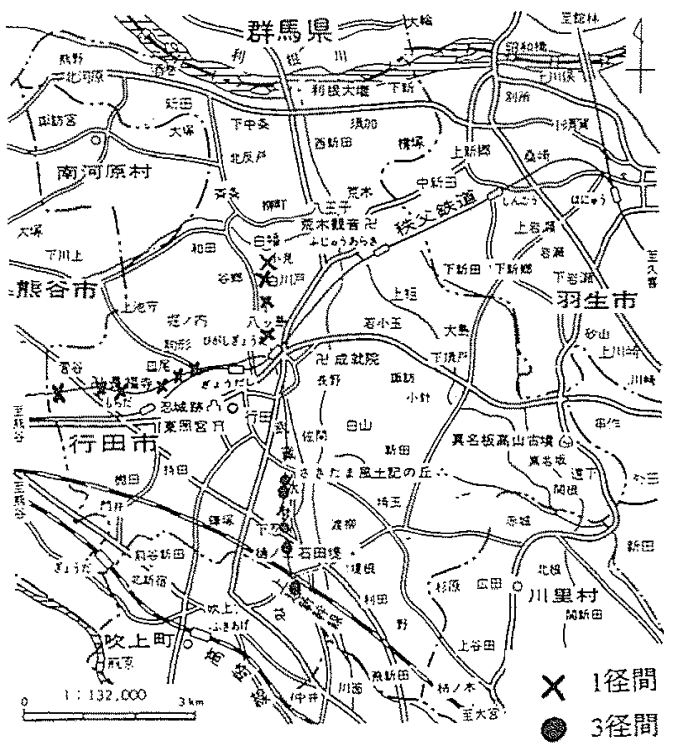

図 1 恐川橋梁群の位圈
下級の線区または線路一転用されたり、構造物の部 材として使用されることが大正末期から第二次大戦 後の物資不足まで多かった 2)。のためかなり古いレ 一ルを使用した構造物が現在でも確認できる。これ らがレ一ル史研究の一大宝庫を形成しているのであ る ${ }^{3 \mu 。}$ 。古レールを再利用したことの理由として、物 を大切にする精神からだけでなく、その性質が一般 粠造用鉶材に近いので加工が容易であり、かなり広 く使われていたことが举げられる。また、加工費が少 なくすむため経済的にも受け入れられた。特に昭和 初期の我が国は、戦時下の昭和 16（1941）年に国家 総動員法に基づく「金属回収令」(レールを回収して 軍用に転用するため、不用不急線の単純化、鋼索鉄道 の休・廃止等を行ったもの) が公布・施行されたのを きっかけに民間用鋯材が非常に不足していた。さら に終戦後には鉄道網が延びはじめレ一ルの架け整え が多く行われ、古レールは何かに使えないかと考え られていた時代であった。

(2) 古レ一ルの再利用例一跨線粯一

レールの変遷については、西野、小西、淵上らが謈 筫して体系的にかつ実証的に組子立てた研究がある 34)。それによると古レールの再利用例はクレーンレ 一几や乗降場屋根部材、跨線橋の部材、線路用地境䛺 桶、乗降場や洗熦台の下部部材、士留梱、架線柱、レ 一ル析等の仮設部材など鉄道関係によく晃られる。 ここでは古レール再利用の代表例として跨線橋に使 用されているものを取り上げ、一般に橋梁部材とし

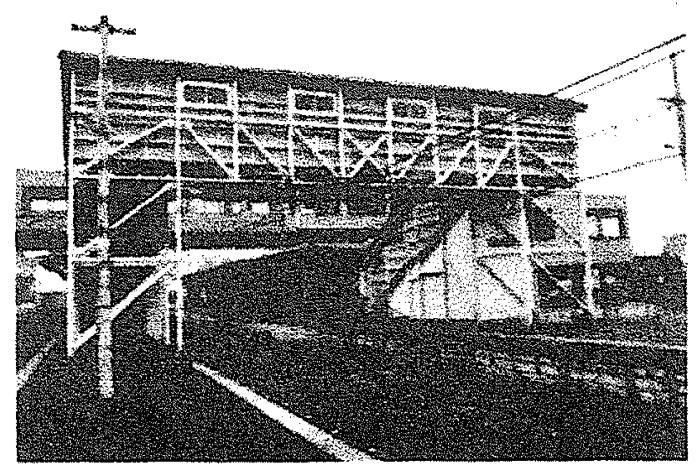

写真 3 トラス組みの跨線人道橋

（JR 東北本線氏家歌、撮影：渡辺、1996） 
テ、ビの部分に、どけ上うな形で使用されているのふ 学把握寸ることにした代表的な⿱中心が西野二上る 参考文献引記されている。古レールによる跨線膘! 一般に写真引の上うにレール在部材としたトラス、

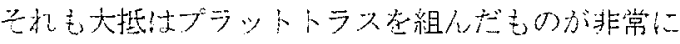

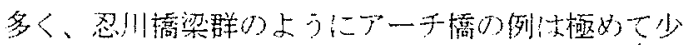
ない: その一例上して最も有名な写真 4 ひ飛鳥山下 跨線人道樀（JR 東日本東北本線、中路式ブレースド リブ固定アーチ、大正 14(1925)嵱工、槅長 42m、幅員 $2.74 \mathrm{~m}$ ）が劣る。これは参考資料2!紹介されており、 材料!明治 13（1880）年から同 42（1912）年にか汁 て、イギリス等外国で製造されたヨーロッパ形断面 の第 1 種 60 封度軌条という30kg レールで、初期の 銅レールであるが数が多く、つい最近まで各地の側 線などに残っていたという。他に図2に示寸東武伊 勢崎線栗橋駅の) 它) (昭和 26(1951) 竕工、橋長 27.69m、

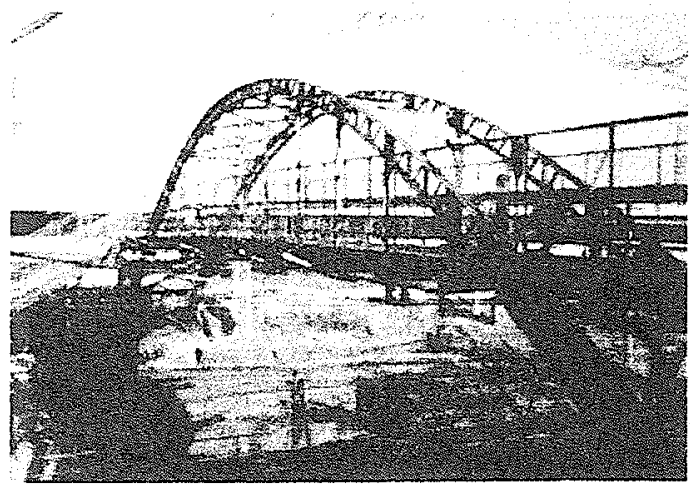

写真 4 飛鳥山下跨線人道橋 （JR 京浜東北線王子駅、撮影：渡辺、1996）

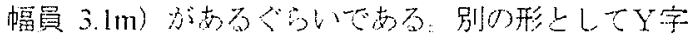
型にレール在組斗合すせ、シーメン撟いように見え

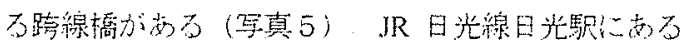

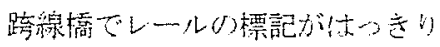

COCKERILL - XII 1923 - 60LBS - ASCE - IJGR と読め、ベルギーのコッケリル社製であるこレがわ からた。 1927 年から性よんど国産で占められるよ

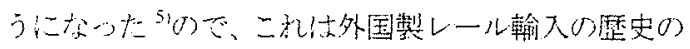
終わり告げるものとも言える:

\section{3. 忍川橋梁群の調查結果上考察}

\section{(1) 調查過程}

序論で述心゙たように現地調查で鋼材に刻印がある

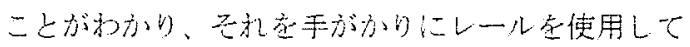
いるかどう方確認寸ることが考え的、また行田 市役所の台帪に上り昭和 8 年に架設されたこ上がわ

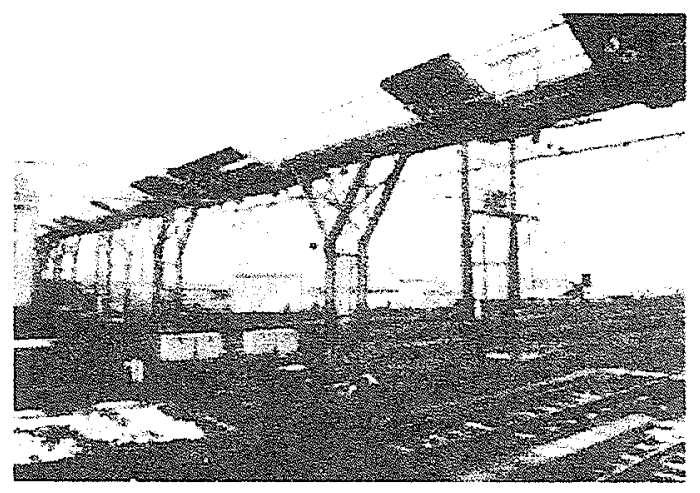

写真 5 Y宇型槁脚 $\circlearrowleft$ 跨線人道樀 (JR 日光線日光駅近く、鼬影：渡迅、1996)

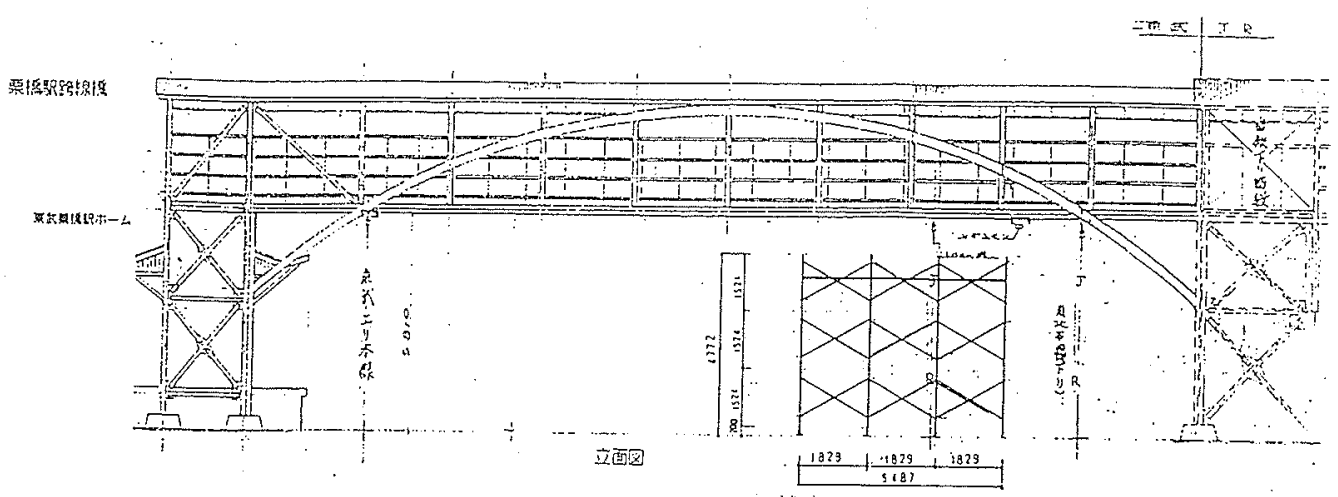

図2東武伊勢崎線栗橋駅跨線人道橋図面の一部 
かった。より詳細な情報を得るために市役所や県土 木事務所に問い合わせると、設計と施工は県が担当 した後、知事から市へ出来上がったものを委託した とのことである。 さらに市役所より、当時の担当であ った石島秋氏を紹介していただき図面を得ることが できた

\section{(2) 調查結果}

調査結果は以下のようになる。

a) 全 15 橋存在のうち 3 径間（橋長 $15 \sim 16 \mathrm{~m}$ ）が 5 橋、 1 径間（橋長約 $10 \mathrm{~m}$ ) が 10 橋,

b) 昭和 8 年に架設されたものと、そのときの図面 を基にして昭和 30 年に架設されたものとがある。昭 和 30 年の時に石島氏が 1 橋担当したが、その後の河 川改修で撒去されてしまった。なぜ同じ撟を 12 年も 経た後に架けたのかはかからなからたが、拉そらく 鋼材が不足していたことと経済的なことから古レー 儿を再利用寸る上いう点が有効であると考えられた のであるう。

c）昭和 7 年に県で設計・施工、翌年に完成した橋 梁の図面（付図 1) が元荒川上流士地改良区で、昭和 30 年に行田市で設計・施工した図面（付図 2) が市 役所から見つかった (どちらも1径間):

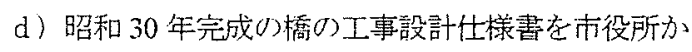
ら石島氏省通して得ることができた。同29 年橋台工 事分上同 30 年上部工事分の 2 冊ある。二机侍予算の 都合上、橋台部と上部工を 2 年に分けて施士したよ うである。

e 現地調查したなかで鋼材の刻印が読めたもりは、

(1) 60A.S. B.S.CO. STEELTON UIIIIII 1920. O.H. (2) CARNEGIE 1907

の子であった（の乞同じものが参考资料中に上り東武 鉄道でレールとして使用されていたニと份かり、

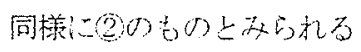

CARNEGIE 1907 E T HIHI: $-\mathrm{T}$ T $\mathrm{K}$ 汾使市れていたと記されて南るので、東武鉄道のも の上推測できる。また図面に 60 封度軌条 $(30 \mathrm{~kg} / \mathrm{m})$

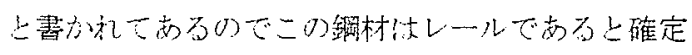
できる：昭和 30 年に行すれた架設の設計仕様書にレ 一ルの摘要の欄に“甫支給品”よあった。需要がある 都度レール在買っていたりではなく、市で圭よか買
いしておいたのであろう。

f）沓部の鋼は鋳物である（写真6、図3）。

g）レールを加工したの㥓玉県媣谷市にある湯本 鉄工所であった。担当されてたのは初代であるが、令孫 にあたる湯本元始氏 (現代表取締役)にお話を伺うこ とができた。

本鉄工所が受け持つ工程は橋梁鋼材部の加工から 架設までである。その手順は(1)原寸をおこす（設計図 を基に原寸大の図を板に描く)(2)R定規・シナイの製 作(3)材料の加工(4)工場内での仮組(5)架設となってい た。R定規とは原寸図からアーチの曲線をとった定 規のことで、これを当てながら少しづつレールを曲 げていく。またシナイとはその名のと打り柔らかく しなってたわむ薄い物差しのようなもので、これを しならせて原寸図のアーチ部分に当ててボルト位置

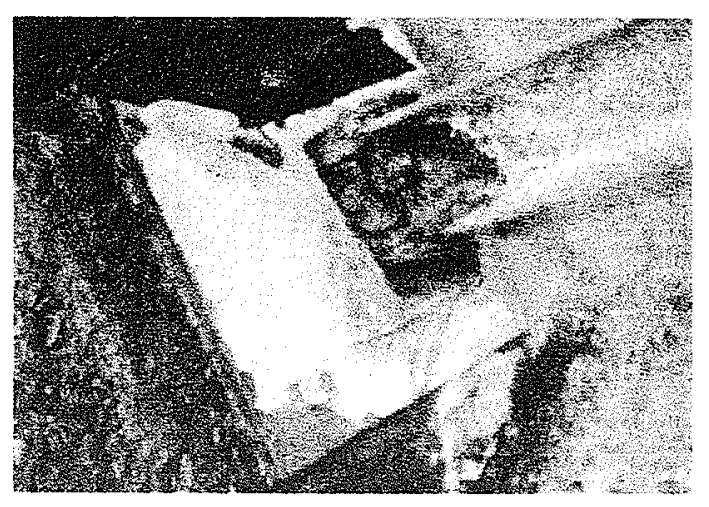

写真 6 沓部门鋳物（撮影：渡辺、1996）

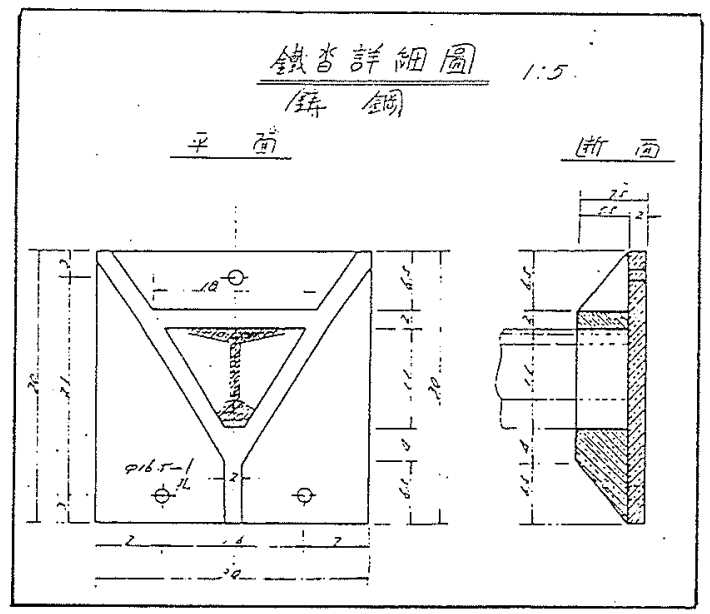

図 3 鐵登詳細図（行田市役所提供） 
の印を付ける、しなりを戻せばアーチ部を直線にし た場合のボルト位置がわかる、つまりレールをアー ヂに曲げる前にシナイを当ててボルト位置の印づけ をしておくのである:レールを曲げる器具は“じんく ろ”と呼ばれるもので、現物はすでに無く、見ること ができなかった。ジャッキのようなもので、R定規を レールに当てて焼きをいれながらネジを回して少し ずつ圧力を加えて曲げていくのだが、その曲汁加減 は職人の勘に頼るしかなく熟練した技が必要であっ た。他にくの字型に曲げる器具として“はちのす”(こ れも現物は無い)があり、鋼材の切断にも使われてい た（本橋梁のレールの切断はおるらくガスであった とのこと）。当時㳉与えられた道具というものはなく これら必要な道具を一つ一つ作ることから始まり、 さらに職人の勘を生かして時間をかけて丁寧に造り 上げられていったのである。

（3）河川改修と槁梁架設の関係

本橋梁群は大正 8（1919）年加昭和 12（1937） 年の 20 年間の間に行われた元荒川改良事業（図4) で誕生した構造物であった。当時、昭和初期は全国的 に農業用水、河川改修、土地改良が盛んに行的れ、昭
和 11 年頃が最盛期だった ${ }^{\circ}:$ 特に埼玉県は全国的に みて、用排水幹線改良事業がもつ上も盛儿に行かれ、 大正 12 年から昭和 16 年までの累計をみると、受益 地区数、面積、事業費とも全国一位であった。橋梁に 古レールを使用したのは2。で述べた時代背景の他 に、河川改修による必要性、経済的なこ上があったと 考えられる。この用排水事業の内容には堰堤などの 構造物の改造も含まれていたが、その主体は水路の 改良を中心とするものであった。なおこのことは耕 地整理事業が、田畑の区画整理よりも、むしろ用排水 の基幹水路を改修寸ることに重点を置いたことと結 びっいて耕地整理事業をより効果的に寸る役割を担 ১た。

\section{5.おわりに}

現在、忍川は拡幅工事が行われて扔り、今回研究対 象とした橋梁群は数年後に法掛け替えられてしまう 上のことである。先人の、物を大切にする精神と、時 間をかけて一つ一つ丁寧に手で造り上げていいたも のが消えてしまうの残念である。

最後に、本論文の作成にあたり、ご多忙の中、跨線

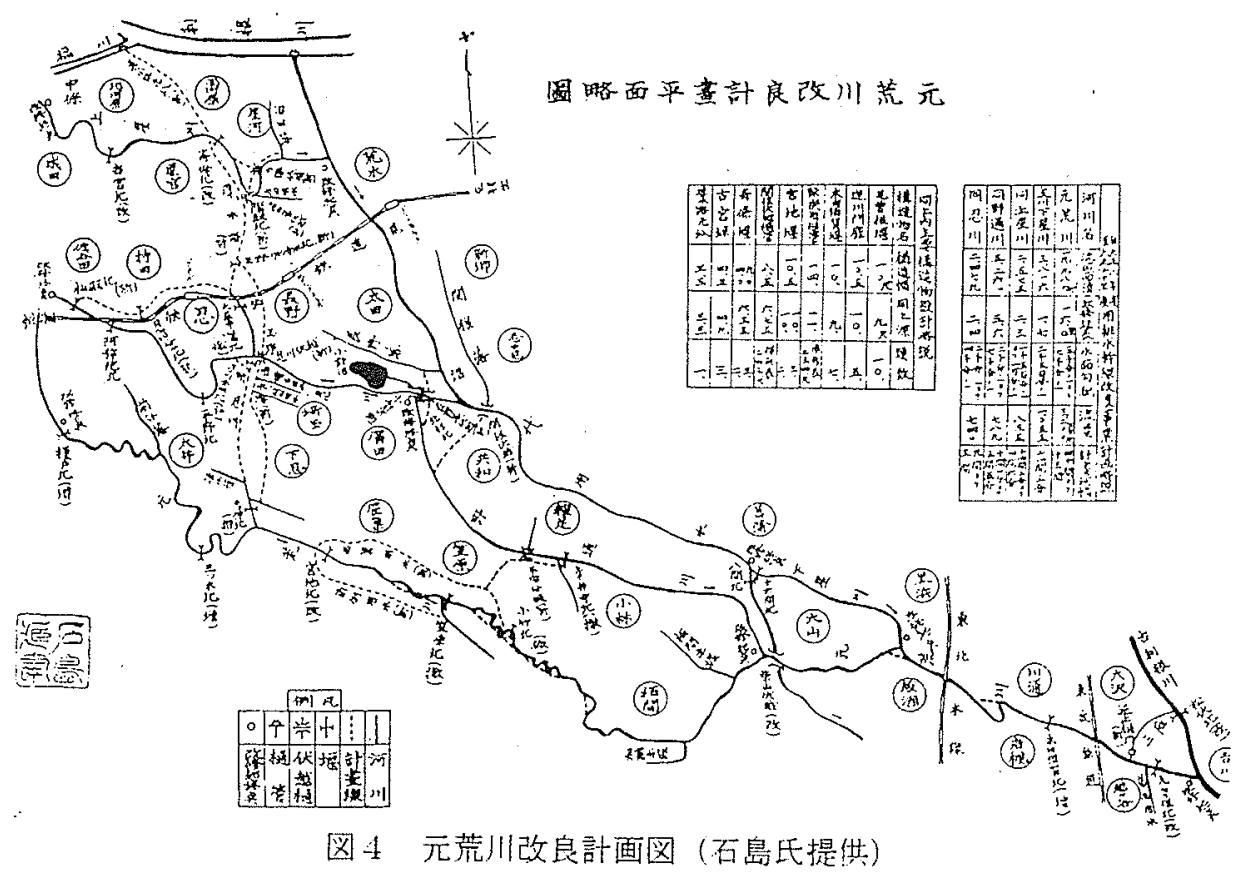




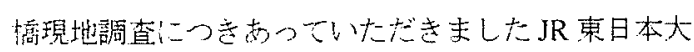
宮の服部氏、伊藤氏、レール加工について丁寧にご説 明くださった湯本氏、そして、本研究の密口坴開いて くださった石島氏には大峦お世話になったここに 記して心か心感謝の意在表打次第です

\section{【参考文献】}

1) 渡㳄明子・伊藤学・洼田陽一：「埼玉県内心歴史 的橋梁の実態調查とデータベース化、第 15 回日本土 木史研究発表会論文集, 士木学会,pp533～540

2)成瀬輝男：『鉄の橋百選』，東京道出版，1994.8

3) 西野保行・小西純一・淵上龍雄：「日本に抋ける 鉄道用レールの变遷一残存士る現物り確認による追 跡一」,第 2 回日本土木史研究発表会論文集,士木学 会,pp.30〜37.1982.6

4) 西野保行・小西純一・淵上龍雄：「日本に执ける 鉄道用レールルの変遷一残存する現物の確認による追 跡（第 2 報）一」,第 3 回日本土木史研究発表会論文 集,士木学会,pp.126〜135,1983.6

5)西野保行：『鉄道史見てある記』,吉井書店,1975

6)『埼玉心土地改良』,埼玉県士地改良事業団体連 合, 1977.3.24

7)行田市史編纂委員会：『行田市史下巻』,行田 市役所.1964.11.3

8)『東武鉄道 65 年史』, 東武鉄道株式会社 1964.10

9) [BRIDGES AND TUNNELS』,JR 東日本, 1990.3 


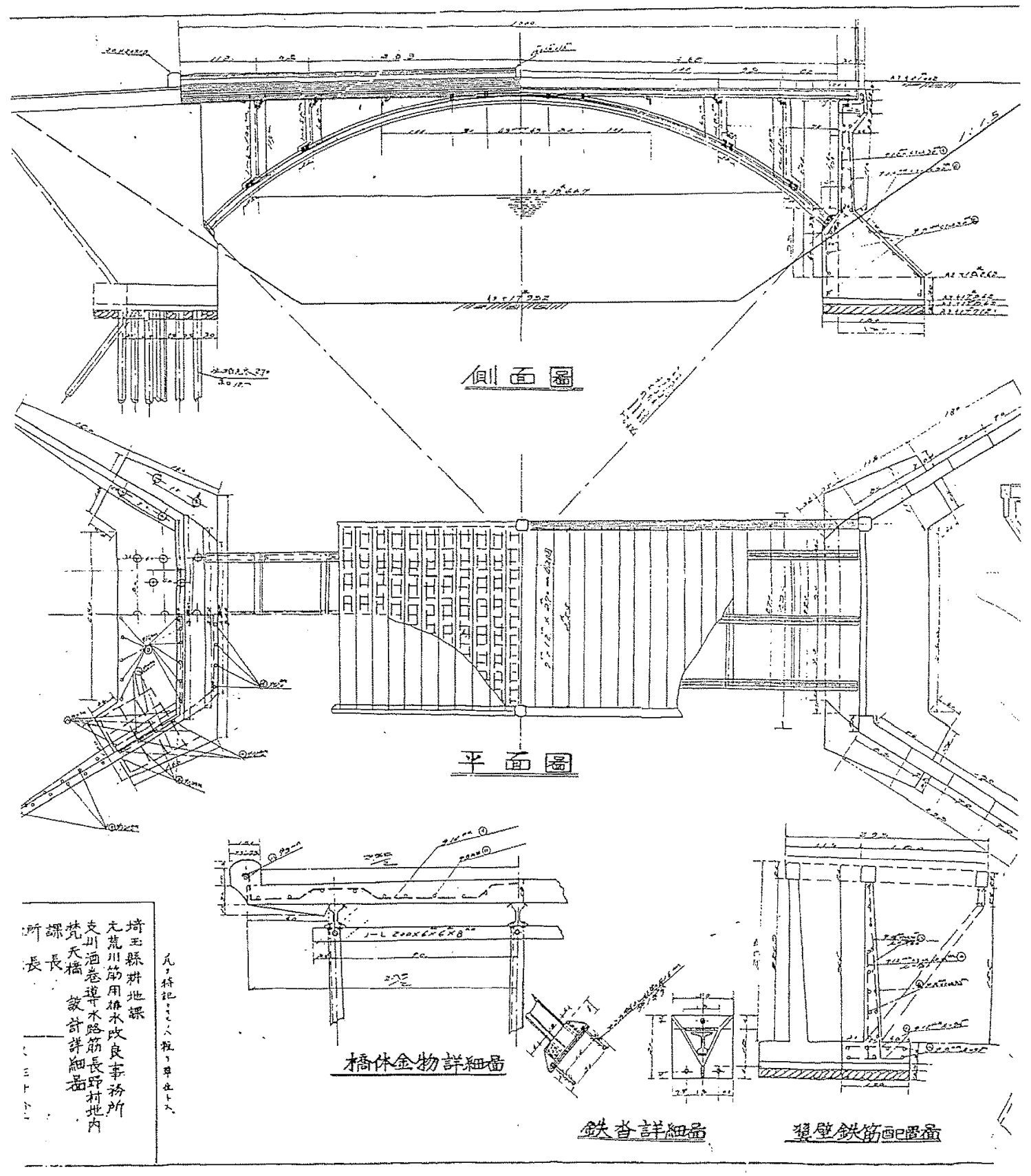

付図 1 昭和7年㸾川橋梁図面の一部（元荒川上流士地改良区提供） 


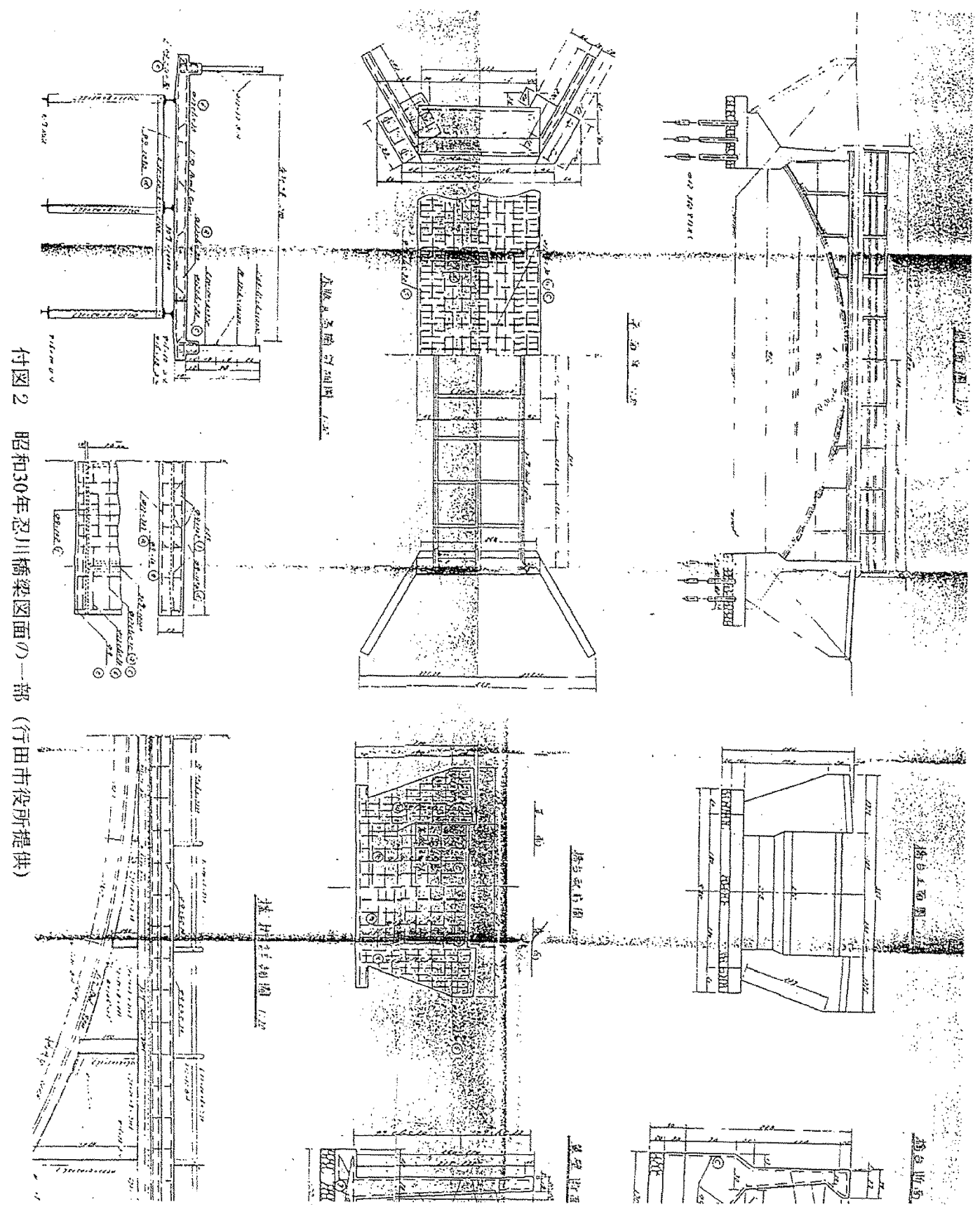

